\title{
THE EFFECT OF SOCIAL REHABILITATION ON THE URBAN SEGREGATIONS
}

\author{
Dávid FEKETE ${ }^{a}$, Tímea LACZKOVITS-TAKÁCS ${ }^{\mathrm{a}}$
}

a Széchenyi István University, H-9026 Győr, Egyetem tér 1., fekete.david@sze.hu; takacs.timea@sze.hu

Cite this article: Fekete, D., Laczkovits-Takács, T. (2019). The effect of social rehabilitation on the urban segregations. Deturope. 11(2), 143-168.

\begin{abstract}
The remarkable social urban rehabilitation effort of the Györ Municipality which has recently been implemented and is currently in progress led to the considerable development of Györ-Újváros, not only in the renewal of the actual built environment but also in the social improvement of the inhabitants. In our study we will look at the Györ urban development project in three dimensions. First we explore its feasibility. Why is it Újváros that needed rehabilitation? Strategic documents and relating statistics prove the choice feasible: it is the place where the most significant segregation can be found in Györ that needed intervention. Secondly, we analyse the intervention of the urban development. What were the changes, how did they affect the built heritage and the social status of the inhabitants of the area? Based on the available documents and reports we can state that significant results were achieved both concerning the built heritage and social adjustment and development. In the framework of empiric research, we examine through comparative analysis the conditions before and after the rehabilitation taking into consideration two aspects (modification of hard infrastructure and the modification of the soft factors) and 7 allocated indicators (I.1. Number of flats, I2 Number of businesses, I3. Level of convenience, I4. Surface area of the flats, I5. Rent prices, I6. Applicants receiving regular support, I7. Applicant receiving temporary support). Data are available partly from the feasibility study and partly from the data services of the Györ Municipality.

Result show that regarding several factors, rehabilitation had a positive effect in the neighbourhood. As a result of the rehabilitation the built environment has gone through significant improvement in case of six blocks of flats. The number of businesses for rent has increased, the convenience level of flats has changed positively too, as all flats have all modern conveniences and in most cases the surface area has also risen, thus providing better housing. Parallel to this the social status of the inhabitants living in this area has also improved as both the regular and temporary applicant receiving support has dropped significantly. Due to rehabilitation the rents have tripled after renovation which can be put down to the significant rise in standards.
\end{abstract}

Keywords: social urban rehabilitation, housing policy, local social supply system, Győr, segregation

\section{INTRODUCTION}

The study focuses on the topic of social urban rehabilitation. The rehabilitation and revitalisation of an urban area is often among the strategic goals of Hungarian and European cities. There are more ways to raise an impoverished area, in this case we will look at the social urban rehabilitation. After the introduction of the literature we will list our research questions, data resources and methodology.

The empirical examinations deal with the social urban rehabilitation of Györ. The first phase of the rehabilitation in Györ-Újváros has been finalised, which provides a possibility for comparative analysis in which we evaluate the procedures. We hope that the Györ case study 
is able to summarise important experiences and publishing the good practice may serve as a beacon to other cities and also increase the number of published research results in the field of urban rehabilitation.

\section{THEORETICAL BACKGROUND}

Györ in the recent years has been the centre of several scientific research projects. The key to the significant development of the city is the strong economic base which was a popular topic of research. Several researches looked at the Györ Model through which the procedures of a strong co-operation between the university, the industry and the city were examined. (Rechnitzer et al., 2016). Further examination of the Györ co-operation model highlighted the fact that strong co-operation plays an important role not only in the city's but also the region's competitiveness as well as in the development of its infrastructure. (Fekete, 2018b). Further analysis of the processes taking place in Györ identified the move towards economic governance. (Fekete, 2018c). The companies are significant participants of the Györ Model and have served as an important research topic in the past few years. The openness of companies (Czakó \& Hajdu-Smahó, 2014), the mapping of the contact network of companies (Reisinger, $2014 \mathrm{~b}$ ) and the contribution of business organisations to economic development have also been analysed (Reisinger et al., 2017). Research in territorial capital has not avoided the present procedures in the city and these researches have also evidenced that the co-operation systems of the local economy significantly contribute to the economic development of the city. (Czakó \& Döry, 2016). Taking into account the theory of territorial capital, the analysis focused on the developmental stages of the city and the local economic, cultural and social characteristics. (Rechnitzer, 2016). The most prominent research of the last few years was the research programme on the vehicle industrial district of Györ in the framework of which they mapped using both theory and practice the effect on the city of a dynamically developing sector, in Győr's case the automotive industry. The research among others concentrated on the formation of the city's future image based on the examination of strategic documents (Fekete, 2014), and the track points of Györ's economy from the change of the regime up to today. (Rechnitzer, 2014). One of the most recent research examines social responsibility and the effect of AUDI on Györ's economy (Fekete, 2018a), and also looks at the contact points of five SMEs from the Győr micro-region to AUDI through case studies. Further research touched up the agglomeration of Győr (Honvári, 2014), and the analysis of urban-rural spacial interaction in the context of Györ region (Szörényiné, 2014). The research into the modified role of state role 
with a special regard to Györ was also an interesting field in scientific work (Somlyódyné, 2014). Another locally focused research has dealt with the organisational and territorial efficiency of public services bringing examples from Győr (Dusek, 2014). Further research was done emphasizing the role of local resources with the analysis of Györ's funding strategy. (Kovács, 2014). Many new results have surfaced in the past years in connection to the tasks of human services in Györ. The appearance, effectiveness, fulfilment of basic human needs was also mapped and basic value preferences of the inhabitants of Györ were identified which can help social and health institutions providing human services to respond appropriately to changing needs. (Nárai, 2014a). Besides basic needs further research was conducted into higher activity needs of Györ inhabitants (Nárai, 2014b). In connection to the local health service system the analysis of the regional characteristics of attitudes relating to the health condition of Győr's inhabitants was also (Kovácsné, 2014), and a separate study was done on the provision of local health tasks (Laczkovits-Takács, 2018). The in depth processing of local co-operation was not only done in relation to the economic sector but this field was the centre of interesting research as one of the building blocks of social service activities. (Budai, 2014). Besides city co-operations research also focused on the social co-operation of the Györ area (Budai \& Puli, 2014) and the network structure of the participants of the social institution system their internal, in between and external co-operation contacts (Csizmadia, 2014). The local, Györ society was analysed by several empiric research through which they examined the dimensions of the local society (Tóth \& Ditrói, 2014), the social division of the districts and residential areas of Györ (Páthy, 2014), the Györ identity and their background factors (Bugovics, 2014) as well as the characteristics of social participation of the inhabitants (Reisinger, 2014a). Further studies looked at the structure of a Hungarian metropolis (Csizmadia \& Tóth, 2014), and the social stratification and mobility of the inhabitants of Györ.

In addition to the scientific background from Györ we shortly observe the scientific foundation of the literature on urban rehabilitation. Urban rehabilitation or in other words urban reconstruction means the renovation of residential buildings, flats, social institutions and infrastructure of run down areas with the aim to maintain the characteristic structure, ways of building, and the valuable parts of the building stock (Egedy \& Kovács, 2005).

Deterioration of the built environment usually goes together with the social decay of the area, so for this reason the positive effects of urban rehabilitation must not only be visible on the built environment but the social environment as well. In such cases we can talk about social type of urban rehabilitation which besides traditional tools (renovation of buildings and social spaces etc.), includes economic, social, environmental development programmes as well. In 
the past era several case studies and scientific works were published (McGregor \& McConnachie, 1995, Wrigley et al., 2002, Atkinson, 2003, Yung et al., 2014). Regarding rehabilitation of historical parts of cities several researches can be found in international context examining the practice for instance in United States of America (Anderson, 1967), in Lisbon (Mendes, 2013) or in developing counries (Steinberg, 1996). In European context further studies analysed the phases of urban regeneration in Europe (Stöhr, 1989, Lichfield, 1992), while other works touched the role of public administration in fostering urban housing rehabilitation (Cruz \& de Brito, 2015). Other researches focused on the pratices of urban regeneration activities in several European countries (Alpopi \& Manole, 2013) or the comparison of urban regeneration projects (Aase \& Holt-Jensen, 2003, Holt-Jensen et al., 2004, Holt-Jensen \& Morison, 2000). Another research analysed the urban regeneration activites of the European Union (Tasan-Kok, 2003).

\section{DATA AND METHODS}

In our research we focused on the changes brought about in the first phase of urban rehabilitation in Győr-Újváros area. To begin with our research questions referred to the justification of the rehabilitation. Why was social rehabilitation necessary in this area of the city? How unique is this area? We aimed to answer these questions by analysing the strategic documents of the city and collecting, studying relevant data from the Hungarian Central Statistical Office (KSH).

After this, in the second phase of our examination we looked at the main steps and measures of the urban rehabilitation. By analysing the strategic documents we outlined the most important interventions. As part of the empiric examination we were interested in what changes were brought about in the hard infrastructure and the soft factors by certain interventions? We allocated seven indicators to these two examined factors. (Tab. 1)

Table 1 Examined factors and indicators

\begin{tabular}{|l|l|}
\hline Examined factors & Indicators \\
\hline Change of hard infrastructure & I1. Number of flats \\
\cline { 2 - 2 } & I2. Number of businesses \\
\cline { 2 - 2 } & I3. Level of conveniences of the flats \\
\cline { 2 - 2 } & I4. Surface area of the flats \\
\hline Change of soft factors & I5. Rent prices \\
\cline { 2 - 2 } & I6. Applicants receiving regular support \\
\cline { 2 - 2 } & I7. Applicant receiving temporary support \\
\hline
\end{tabular}

Source: Own compilation 
When selecting the indicators, we looked at six such reconstructed blocks of flats from which the necessary data were available both before and after the rehabilitation. The starting data were taken from the survey of the area involved before the rehabilitation, while the condition after the rehabilitation was reconstructed based on the data received from the Györ Mayor's Office. After the evaluation of data, we analysed the direction of the changes and examined the positive and negative moves of the indicators.

\section{SOCIAL REHABILITATION OF GYŐR-ÚJVÁROS}

To understand the reason why Újváros was chosen as the primary area for urban rehabilitation in the recent years, we must look at the exact numbers, but before we do that we should look back on the short history of the area (Action Plan 2012). The Újváros area lies on the western edge of Györ which was the first area after the middle ages in the beginning of the 16th century that was populated outside the city walls. Development took off after the Turkish era and in the 19th century Újváros became an area redolent of age and kept its character until the 1940's. During the era of development, between the 17th and 19th century, the five denominations besides each other were established and most of buildings of architectural heritage in Kossuth Lajos and Bálint Mihály Street were built. Burgers, rich tradesmen, businessmen and people of handicraft inhabited the area. Unfortunately, during the years of socialism, the state neglected the area and did not spend on the maintenance of the buildings in and around Kossuth Lajos and Bálint Mihály Street so their condition deteriorated and parallel to this people who have leaved there for generations, owners who were made to rent their own property after 1949 and their descendants were forced to move out from the area in the 1970's and 1980's. At the same time the Roma settlements on the outskirts of the city were being eliminated and the council moved in people with lower social status, which process continued even after the change of regime and conserved this situation. After a long period of deterioration and stagnation no steps for improvement were made until 2012.

\section{Main characteristics of the Újváros segregation}

The history of our research topic was examined with regard to two strategic documents, the Integrated Urban Development Strategy of Györ accepted in 2008 (resolution number 41/2008. (II.28.) GYÖR MJV Kgy) and the Integrated Settlement Development Strategy of Györ 
accepted in 2014 (resolution number 162/2014. (IX.12.) GYÖR MJV Kgy). The Integrated Urban Development Strategy (hereinafter IUDS) based on the 2001 census identified the adverse areas of Györ with lower social strata. Using the data ${ }^{18}$ of the situation analysis, the areas were ranked applying three processes ${ }^{19}$ and the following statements were made (IUDS, 281):

- the segregation of social groups with lower status is most recognizable in Újváros, Gorkijváros and Gyárváros one which must be amended by the western part of Újváros and Sziget, where the concentration is less,

- the most deprived area is Újváros as three out of the four indices show the worst data ( $20 \%$ unemployment rate, the rate of inhabitants with low level of education is $61 \%$ quarter of the flats are without basic convenience or are emergency lodgings),

- Based on the population of the areas $2,2 \%$, live in the three worst areas, if we look at the five worst areas of the city this number is already $6,8 \%$. As a result of this we can say that the rate of segregated groups based on these parameters is low, but in case of Újváros the difference is especially big.

The document further examines the groups of low social status, the members of which have only primary school education and no regular income. If the rate of this group exceeds $50 \%$ in an area, it is regarded as a segregation. All in all, it was noted that in average $10 \%$ of the population of Györ can be regarded low status but in no area does it exceed 50\%. However, arising from the division structure of the Györ areas, the concentration of low status inhabitants is the highest in Újváros. Based on the situation analysis of Újváros has the following characteristics:

- Cumulatively disadvantaged in the area,

- Concerning the age division the rate of children under 14 is outstanding which also reflect that the number is children is high, ${ }^{20}$

- In the kindergarten of Újváros the rate of cumulatively disadvantaged children exceeds $60 \%$,

\footnotetext{
${ }^{18}$ The used data were the following: convenience index for employment, unemployment, education and housing and the newest data of social support and rentals.

${ }^{19}$ The three applied procedures were the following: ranking, preparation of a unified development index with data reduction and cluster analysis

${ }^{20}$ Number of children per 100 families is 139 which is way above the city average
} 
- The is a deficit concerning the number of active aged inhabitants and as a result their status on the labour market is also unfavourable,

- The number of flats without basic convenience is the highest in Újváros,

- The number of flats owned by the municipality exceeds $40 \%$,

- Based on the two basic indices defined by the handbook of urban development the area is above the $50 \%$ criteria (rate of people with only primary school education is $61,4 \%$ while the rate of inhabitants without regular income is $62,8 \%$ ),

All in all we can state that based on the 2001 census Újváros is a big, contiguous segregation, forming an area within the city characterized by disadvantageous situations in more than one dimension where if you take into account the guidelines of the anti-segregation plan the concentration of low status inhabitants is higher than 50 so it can be regarded as the city's primary target area together with the bordering areas of Sziget for the anti-segregation programme. The intervention areas of the programme focus on housing, education, labour market integration, improvement of services, and as part of a general development project, the rehabilitation of Újváros by forming a cultural quarter including the reconstruction of buildings, functional expansion and the development of roads and the utility network.

The relevant chapter of the Integrated Settlement Development Strategy (hereinafter ISDS) based on the 2001 data contains the analysis of the actual relations of areas marked segregated or in danger of segregation assisted by data from the 2011 census. Analysing these data we can formulate the following points:

- Improvement is detectable in the field of employment, in case of Újváros we can see a $5 \%$ growth in activity during the past 10 years and parallel to this the number of inhabitants without permanent income has dropped,

- However, the rate of unemployment is still high,

- Among the active inhabitants the percentage of people with only primary school education is still high but we can see a continuous upward shift,

- The rate of low convenience flats is still high especially in case of Újváros

Practically there has been a positive change in the past 10 years in all indices measuring development.

The Department of Welfare of the Central Statistical Office based on the 2011 census data, located three segregations (Tab. 2) and three areas in danger of segregation (Tab. 2). Based on 
the segregation index we can talk about segregation when the rate of inhabitants between 1559 with only primary school education and no regular income exceeds 35\% (312/2012. (XI.8.) Government Decree).

Table 2 Segregations in Győr (2011)

\begin{tabular}{|l|l|}
\hline Name & Streets included \\
\hline Segregation 1 & Veszprémi Street, Szent Imre Street, Kismegyeri Street \\
\hline Segregation 2 & Majorok Street; Pásztor Street; Síp Street \\
\hline & $\begin{array}{l}\text { Bercsényi Grove, Erkel F. Street, Kossuth L. Street, Jakobinus Street, } \\
\text { Bálint M. Street, Beér Close, Kossuth L. Street, Transzportház Street, } \\
\text { Bálint M. Street, Budai N. A. Street, Selyem Street, Sütő Street, Budai } \\
\text { Segregation A. Street, Cukrász Close, Rózsa Close, Kossuth L. Street, Budai } \\
\text { N. A. Street, Festő Street, Városház Close }\end{array}$ \\
\hline
\end{tabular}

Source: Own compilation based on the General Assembly decision 142/2016. (IX.23.)

The 3rd segregation in the table is the biggest segregation in the city, in 2011384 people were living in the involved streets which can be found in Újváros. From among the data characterizing the segregation we can point out the rate of inhabitants among the active population with only primary school education is $52,5 \%$, the rate of inhabitants among the active population without regular income is $65 \%$ and the rate of low convenience flats, researchers $30 \%$. Based on the data from 2011 we can say that Újváros is the area most affected by segregation.

As the source for the economic and demographic indices data from the census of 2001 and 2011 collected by the Central Statistical Office was used together with the foundation analysis prepared for the Settlement Concept and Integrated Settlement Development Strategy. Regarding certain indices there were precise data available in 2001, which are summarised in Table 3. In case of all the indices we can say that during these 10 years there were positive processes. The population of the area shows a very small, $1 \%$ growth which means 56 people. In case of the activity rate which shows the rate of the economically active population within the working population, we can see a significant positive change since 2001 . In connection to this, the decrease of inhabitants without permanent income enhanced the positive tendencies. Concerning education, the rate of inhabitants with only primary school education is still high compared to the city's average but there has been a drop in these numbers as well. If we look at the rate of inhabitants with university education we can also see a salient, 9,9\% increase. Examining the age distribution this area differs from the other areas because of its high rate of young inhabitants. Looking at the unemployment rate we can still see high figures. In Újváros 
the rate of low convenience loggings as well as the rate of municipality owned flats is still high. (Tab. 4)

Table 3 Change of certain indices of Győr-Újváros (2001-2011)

\begin{tabular}{|l|c|c|}
\hline Name of the index & $\mathbf{2 0 1 1}$ & $\begin{array}{c}\text { Change compared to 2001 } \\
\text { (\%) }\end{array}$ \\
\hline Inhabitants (per person) & 5672 & 1,0 \\
\hline Rate of activity (\%) & 53,2 & 5,4 \\
\hline $\begin{array}{l}\text { Rate of inhabitants without } \\
\text { permanent income in the population } \\
\text { between 15-59 (\%) }\end{array}$ & 43,7 & $-5,7$ \\
\hline $\begin{array}{l}\text { Rate of inhabitants with only } \\
\text { primary school education in the } \\
\text { working population.(\%) }\end{array}$ & 21,4 & $-6,0$ \\
\hline $\begin{array}{l}\text { Rate of inhabitants with higher } \\
\text { education degrees in the population } \\
\text { older than 25 (\%) }\end{array}$ & 19,6 & 9,9 \\
\hline
\end{tabular}

Source: Own compilation based on the Central Statistical Office (KSH) census in 2001 and 2011

Table 4 Győr-Újváros in relation to certain indices (2011)

\begin{tabular}{|c|c|c|}
\hline \multicolumn{2}{|c|}{ Name of the index } & 2011 \\
\hline \multirow{3}{*}{ Age group $(\%)$} & $0-14$ years old & 15,9 \\
\hline & $15-59$ years old & 65,9 \\
\hline & above 60 years & 18,2 \\
\hline \multicolumn{2}{|l|}{ Ageing index } & 1,15 \\
\hline \multicolumn{2}{|c|}{ Rate of households without any person employed } & 29,1 \\
\hline \multicolumn{2}{|c|}{ Rate of unemployed (\%) } & 8,1 \\
\hline \multicolumn{2}{|c|}{$\begin{array}{l}\text { Rate of permanently unemployed within the } \\
\text { unemployed }(\%)\end{array}$} & 60,9 \\
\hline \multicolumn{2}{|c|}{ Rate of low convenience level flats (\%) } & 13,4 \\
\hline \multicolumn{2}{|c|}{ Rate of municipality owned flats (\%) } & 13,9 \\
\hline
\end{tabular}

Source: Own compilation based on the KSH census on 2011

\section{Measure of Urban Rehabilitation in Újváros}

Both nationally and locally before the change of regime very little emphasis was put on the maintenance of the building stock, the necessary renovations, though in the 1980's there were experimental attempts but the problems of the built environment cumulatively appeared after 1990 and these areas with rundown buildings and building stock had a significant disadvantage on the property market. Before 2012 from among the urban rehabilitation actions performed in the action area, we must mention the renovation of the Synagogue in Kossuth Lajos Street and the construction of Rába Quelle Spa in the place of the old spa, performed in the vicinity of the action area (Action area plan 2012). 
For the rehabilitation of Újváros the first bigger step was taken in the framework of the West Transdanubian Operative Programme in 2011 as part of the first round tender documentation (Decision of 38/2011. (II.25) the Györ General Assembly) then in the second round tender documentation in 2012 with the approval of the final Action Area Plan in the framework of the tender „Social Urban Rehabilitation in the Area of Győr-Újváros” (Decision 133/2012. (V.25.) of the Györ General Assembly) The first phase of the urban rehabilitation project was carried out between 01.11.2012. - 31.12.2014. The defining of the action area and other elements of the project are shown in Fig. 1. The project contained infrastructural, investment type and soft elements as well which have been implemented in the form of the below interventions:

1. Infrastructural and investment type development elements

- Activities enhancing housing: 40 modern flats in 6 buildings were made as part of the social housing scheme (Kossuth Lajos Street 15., 19., 21., 22/B., 26., 28.),

- Community service activities: External renovation of the Szent József Roman Catholic church in Újvárosi,

- Developments in the public sector: Establishment of a police station on the ground floor of Kossuth Lajos Street 13; Renovation of the facade of Kossuth Lajos Primary School (Kossuth Lajos Street 13.),

- Development of public spaces: Rehabilitation of the public space in Bercsényi Grove (between Híd Street and Jakobinus Street) - establishing a park, a playground, a traffic park, waste in Bercsényi Grove,

- Service providing units of economic function- 5 shops were established on the ground floor of the buildings number 15, 19 and 26 in Kossuth Lajos Street.

2. „Soft” elements supplementing the infrastructural, investment type developments

- Medical actions targeting the inhabitants of this area: Medical screening

- Providing community developing, free-time services, courses, training programmes: training experts, adult and children (trainings helping adult integrate and/or reintegrate into the labour market, involving disadvantaged youth training programmes, school programmes (Kossuth Lajos Primary School),

- Activities enhancing and forming local environmental friendly, sustainable attitudes, 
- Expanding family welfare services on the on the premises and implementing extra beyond the compulsory social and child welfare services

- Programmes for crime prevention, trainings to strengthen crime prevention and public safety, attitude forming programmes, preparation of local crime prevention strategies and action plans (neighbourhood police programmes, professional prevention programmes, youth protection service)

- Soft activities in indirect policies in the form of mini projects. (these are connected to the soft topic and are restricted to one service, action and do not span through the full period of the project, with the help of civil organisations)

Figure 1 Action area and project elements of the first phase of the social urban rehabilitation project of Újváros

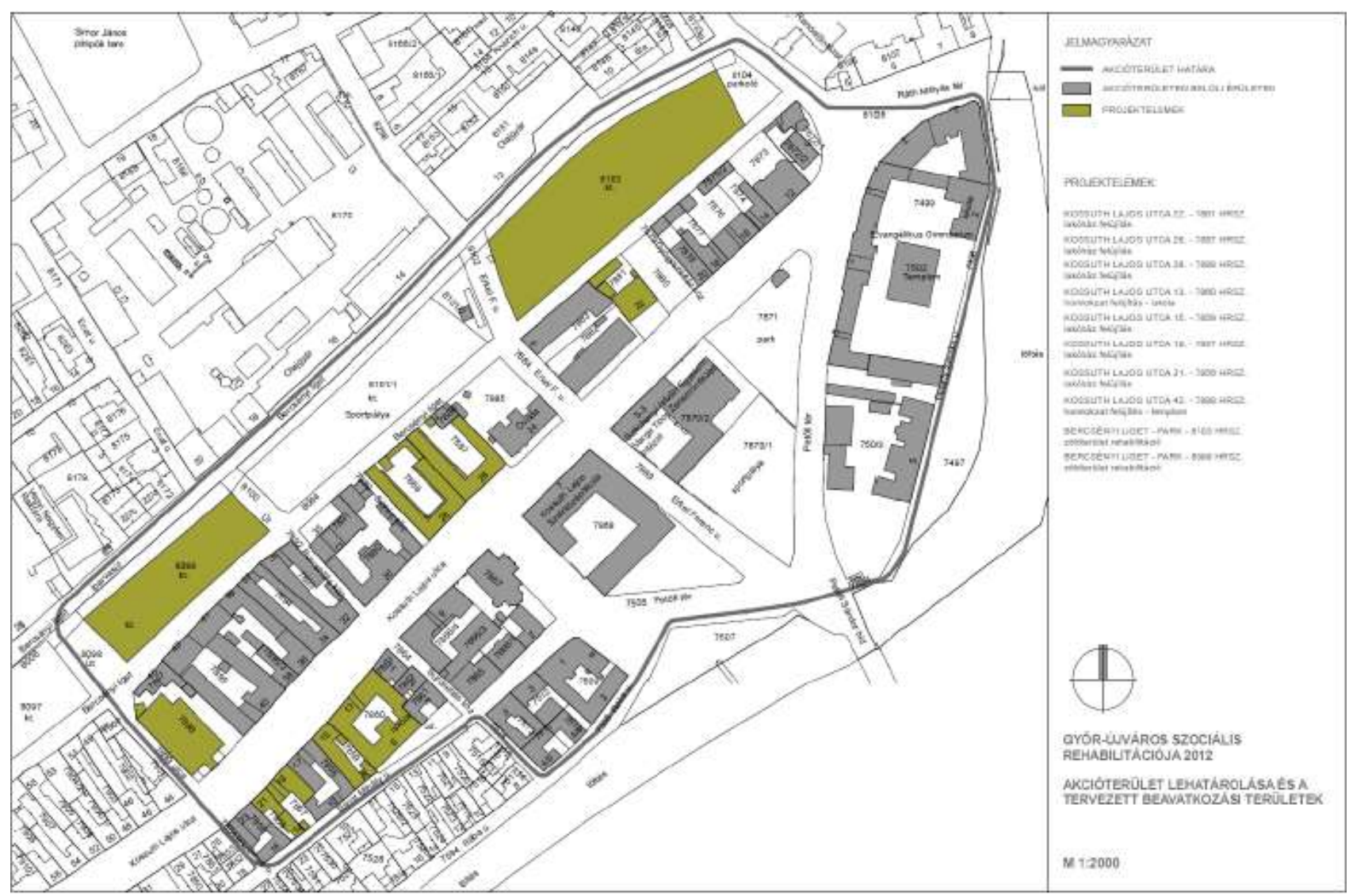

Source: Action area plan page 159

\section{RESULTS OF THE EMPIRIC STUDY}

Situation before the rehabilitation

For the foundation of the project an action area survey was conducted in January and February 2010, which consisted of a question and answer survey and an interview with residential, 
organisational and institutional focus groups. During the survey 72 households were involved, 31 households were not accessible mainly because the flats were uninhabited and people have moved out previously. Concerning house number 6 in Kossuth Street the results were collected and analysed which were supplemented by data provided received from the Mayor's Office of Győr. Table 5 below shows how many households were asked in the question and answer survey. Altogether 15 households in 6 buildings were examined, in case of the other flats they were mostly inaccessible and abandoned. The surface area of the flats was checked in connection to which we can say that the surface area of 1 flat was above $100 \mathrm{~m} 230$ flats were under $50 \mathrm{~m} 2$ while 15 flats were between 50 and $100 \mathrm{~m} 2$ (Tab. 6). The biggest flat can be found under Kossuth Street 26. It is $120 \mathrm{~m} 2$ and 6 people live in it, the smallest flat is also at Kossuth Street 26 , it is $19 \mathrm{~m} 2$ and it was uninhabited. To sum up we can say that most of the flats belong to the less than $50 \mathrm{~m} 2$ category. In the survey the number of people per household was also looked at in connection to which a mixed picture was received. It was interesting to see that 5 households consisted of 2 members, 3 households had only 1 member and the rate of large or multi-generation families was rather low, 3 families consisted of 6 members and 1 family of 7 members (Fig. 2). The classic 4 and 5 member families were totally missing from the sample.

Table 5 Number of flats per building and the number of households surveyed (2010)

\begin{tabular}{|l|c|c|}
\hline Number of the house $\mathbf{2}^{\mathbf{2 1}}$ & $\begin{array}{c}\text { Number of flats in } \\
\text { building/piece }\end{array}$ & Number of households surveyed \\
\hline House 1 & 3 & 3 \\
\hline House 2 & 5 & 2 \\
\hline House 3 & 5 & 0 \\
\hline House 4 & 7 & 4 \\
\hline House 5 & 7 & 5 \\
\hline House 6 & 19 & 1 \\
\hline
\end{tabular}

Source: Own compilation based on the action area survey and data from the Mayor's Office of Györ.

\footnotetext{
${ }^{21}$ Because of anonymity we indicate the buildings not with house numbers but with indications of House 1 , House 2 , etc.
} 
Table 6 Number of flats by surface area and the number of empty flats (2010)

\begin{tabular}{|l|c|c|c|c|}
\hline \multirow{2}{*}{ Number of the house } & \multicolumn{2}{|c|}{ Number of flats based on surface area (per piece ) } & Number of empty \\
\cline { 2 - 4 } & less than 50m2 & $\mathbf{5 0 - 1 0 0 m 2}$ & more than 100m2 & 0 \\
\hline House 1 & 1 & 2 & 0 & 2 \\
\hline House 2 & 2 & 3 & 0 & 1 \\
\hline House 3 & 4 & 1 & 0 & 1 \\
\hline House 4 & 3 & 4 & 0 & 2 \\
\hline House 5 & 5 & 1 & 1 & 15 \\
\hline House 6 & 15 & 4 & 0 & 21 \\
\hline Total & 30 & 15 & 1 & 0 \\
\hline
\end{tabular}

Source: Own compilation based on the action area survey and data from the Mayor's Office of Györ.

Figure 2 Number of household members (2010)

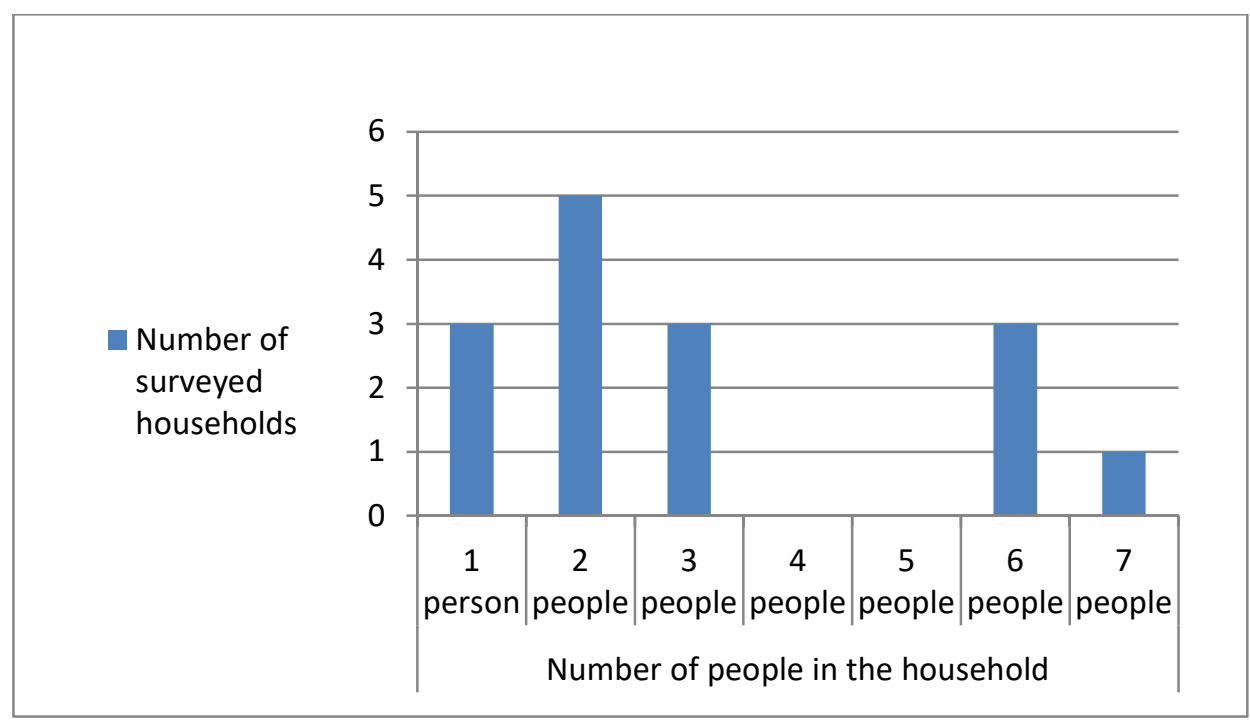

Source: Own compilation based on the action area survey

Similarly to the area data, a negative picture is painted when looking at the highest qualification in the surveyed households (Fig. 3). As the highest qualification 1 person was a qualified, technician, 1-1 has achieved a secondary grammar school or secondary vocational school final exam. 7 people have taken part in vocational training. The number of people with only primary school education was 10 which is very high but the number of people with less than primary school education is even higher. 4 people were not yet in school or attended primary schools. 
Figure 3 The highest completed qualification of the household members surveyed (2010)

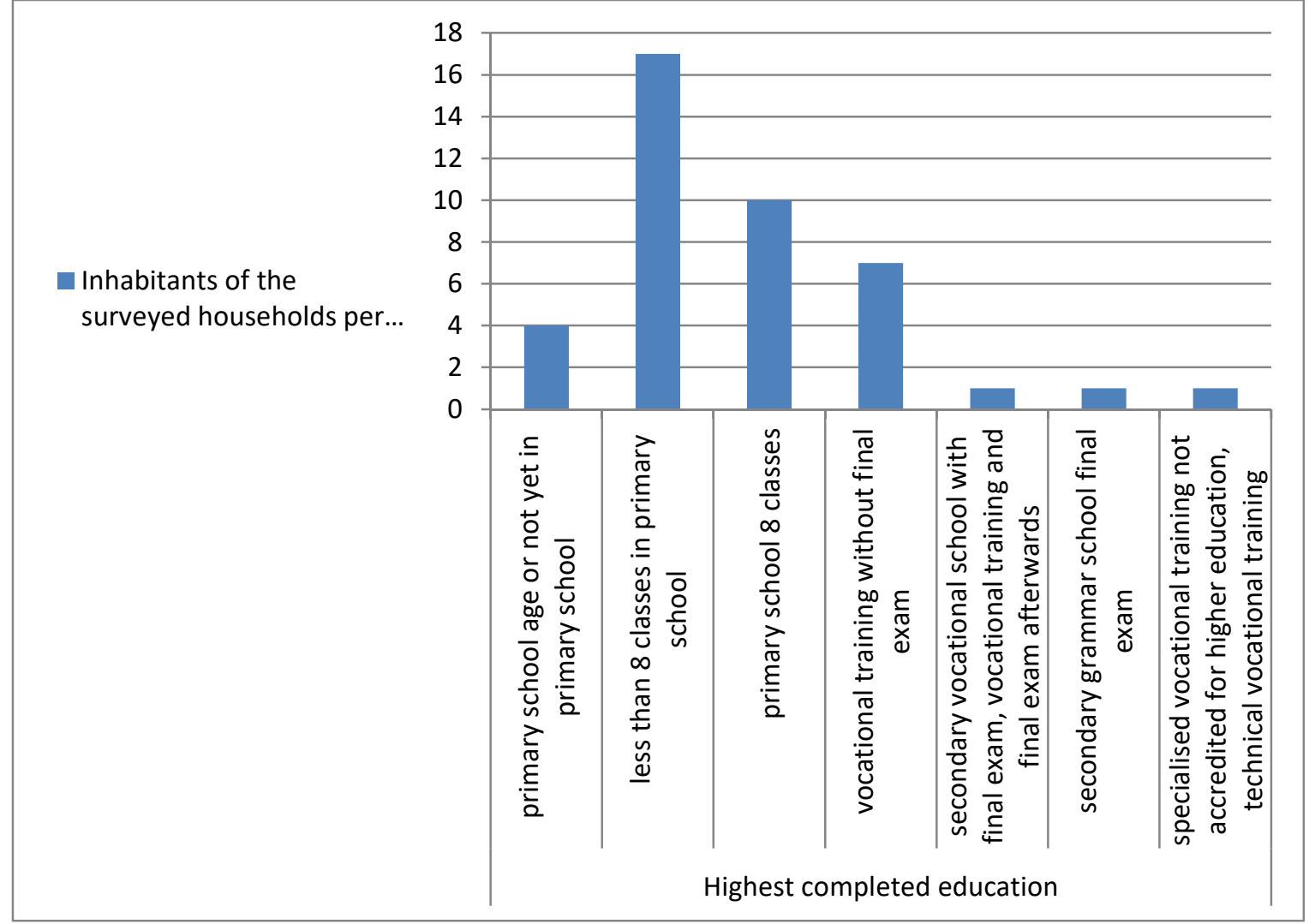

* There is no available data in case of 5 people

Source: Own compilation based on the action area survey

They also examined whether any member of these households received any support in kind or has used any personal services in the past 12 months. Results show that most households (6) got support for schooling, textbooks or child benefit support, in second place was the public health and social catering support, 4-4 households have received such support and in third place 1-1-1 household mentioned that they received family benefit, food, fuel and disability support (Fig. 4 ). 1 household could not answer the question while 5 households have not used any services and did not receive any support. Receiving financial support was also surveyed and here we experience a much more intensive attitude towards the application for these supports. 8 households declared that they have received municipal housing support and 2 households have received housing support for tax reduction purposes. Regular child protection benefit was given to 3 families and 3 families received social support for a member being of working age but unemployed. 2 households got regular social support for disability while one household received nursing support (Fig. 5 ). 
Figure 4 Support in kind, personal service in the last 12 months (2010)

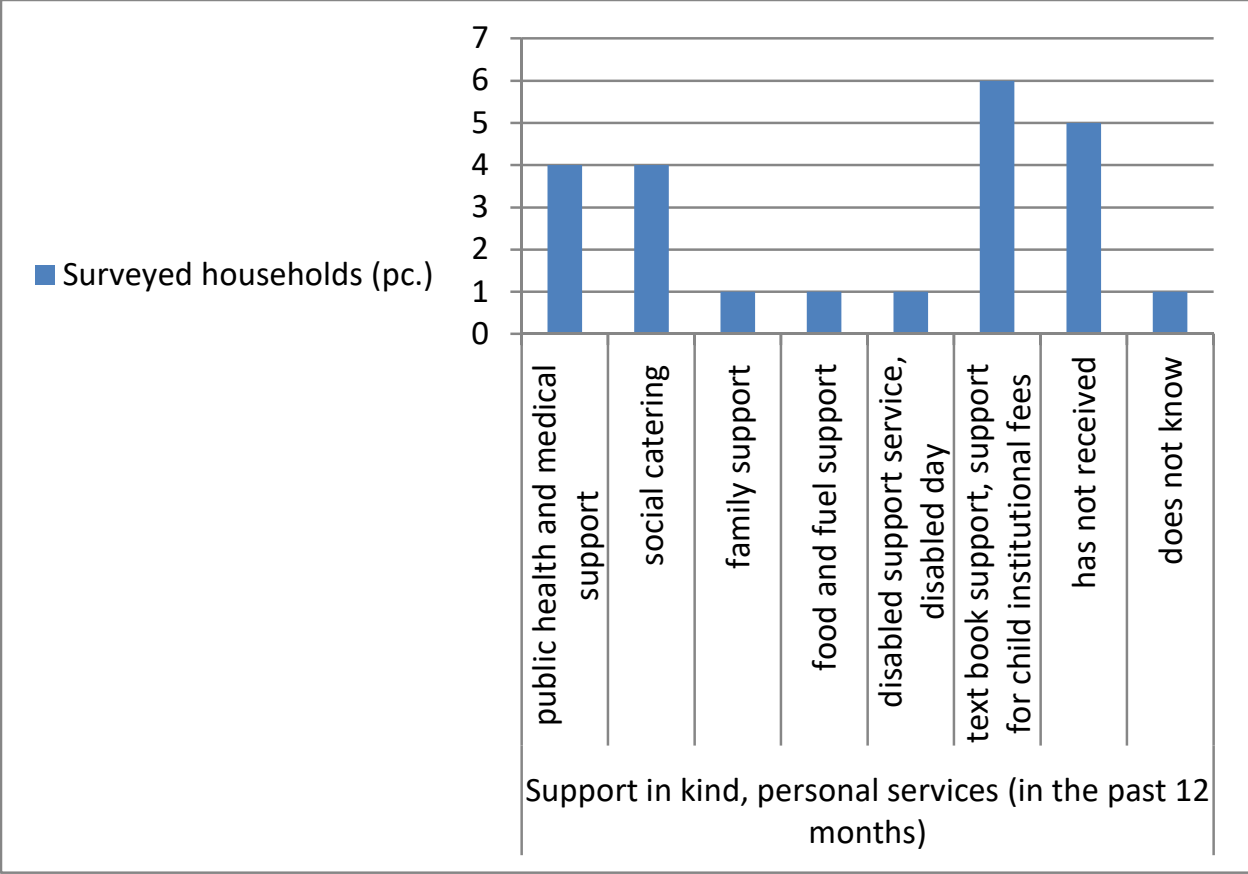

Source: Own compilation based on the action area survey

Figure 5 Social support (2010)

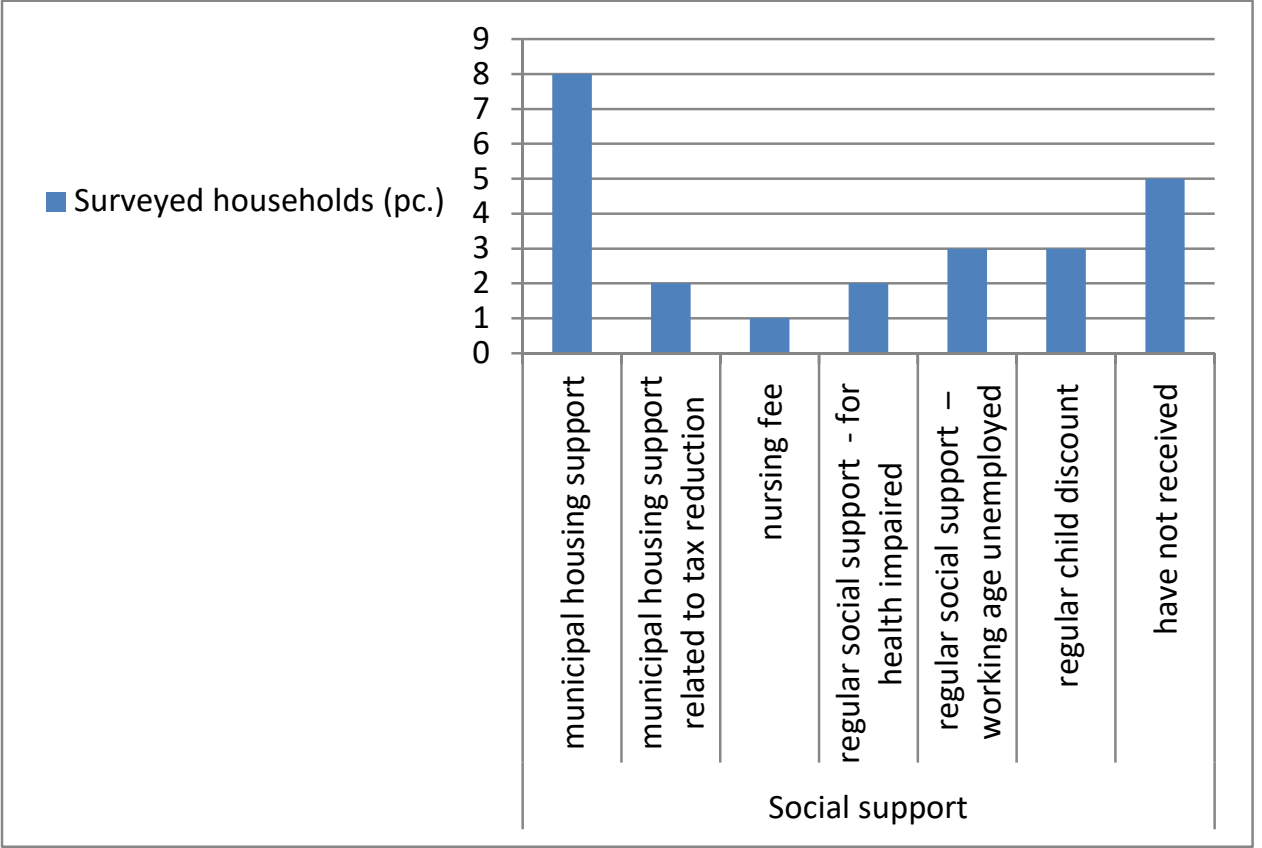

Source: Own compilation based on the action area survey

\section{Characteristics after rehabilitation}

Concerning the inhabitants asked in the action area survey and the building renovated in the first round of the social urban rehabilitation, out of interest we looked at the situation in 2018 including the parameters of the flats, their usage and the municipal support the inhabitants in 
these flats receive. The data are shown in Table 7-8. All in all there were 42 flats constructed, 40 of them are operated by the municipality for social housing, while two of the flats (address Kossuth Street 26) are specially designed for disabled people.

One flat from among the reconstructed flats is more than $100 \mathrm{~m} 2$ in surface area while a little bit more than $69 \%$ of these flats are between $50-100 \mathrm{~m} 2$. The smallest of them is $32 \mathrm{~m} 2$ on size. Furthermore, we examined the social status of the people moving into these flats through the mirror of the social support they receive (Tab. 8). We looked at the regular supports for 2018, including housing, nursing, pedagogical and medical/pharmaceutical support (Municipal Decree of Győr 5/2015. (II.27)). 17 families receive regular support. We also looked at the special settlement support which has been provided 11 times.

Table 7 Number of reconstructed flats by square area (2018)

\begin{tabular}{|l|c|c|c|c|}
\hline \multirow{2}{*}{ Number of the house } & \multicolumn{2}{|c|}{ Number of flats based on surface area } & \multirow{2}{*}{ Total } \\
\cline { 2 - 4 } & less than 50m2 & $\mathbf{5 0 - 1 0 0 \mathbf { m } 2}$ & more than 100m2 & \\
\hline House 1 & 2 & 3 & 0 & 5 \\
\hline House 2 & 1 & 3 & 0 & 4 \\
\hline House 3 & 3 & 2 & 0 & 5 \\
\hline House 4 & 2 & 4 & 0 & 6 \\
\hline House 5 & 0 & 6 & 1 & 7 \\
\hline House 6 & 4 & 11 & 0 & 15 \\
\hline Total & 12 & 29 & 1 & 42 \\
\hline
\end{tabular}

Source: Own compilation based on data provided by the Mayor's Office of Györ

Table 8 Municipal support provided to the inhabitants of the reconstructed houses (2018)

\begin{tabular}{|l|c|c|}
\hline \multirow{2}{*}{ Number of the house } & \multicolumn{2}{|c|}{ Support provided by the municipality (pc.) } \\
\cline { 2 - 3 } & Regular support (household) & Special settlement support (occasion) \\
\hline House 1 & 5 & 2 \\
\hline House 2 & 0 & 0 \\
\hline House 3 & 4 & 1 \\
\hline House 4 & 2 & 4 \\
\hline House 5 & 3 & 1 \\
\hline House 6 & 3 & 3 \\
\hline Total & 17 & 11 \\
\hline
\end{tabular}

Source: Own compilation based on data provided by the Mayor's Office of Györ

\section{Comparative analysis}

Based on the above we attempt to me make a comparative analysis of the situation before and after the first round of urban rehabilitation examining the conditions in 2018 with respect to the 6 reconstructed houses. Concerning the number of flats in the involved buildings we can say that before the rehabilitation there were 46 run-down flats in poor condition with low 
convenience level and after the rehabilitation the municipality had 42 modern social housing facilities, which meant a small decrease in number of flats (Tab. 9) and the number of inhabitants as well. In one building the number of flats increased, in three buildings the number of flats became less and on two buildings the number of flats did not change. Concerning the usage of the flats, prior to the rehabilitation all the flats were operated as social housing facilities. After the reconstruction two flats were turned into modern dwellings with disabled accessibility. In case of all the buildings the dominant factor before and after the rehabilitation was the living function. Three buildings have mixed functions, they possess both living and business function. The business function earlier was represented by four business premises, shops, while after reconstruction this number was increased by one (Tab. 10) and similarly to the flats, the reconstruction both along an increase in quality as well. Under the address Kossuth Street 19 besides the four municipal flats and a shop, public function is represented by a new police station. The positive changes in the convenience level of the flats are shown in Tab. 11. Before the reconstruction more than $24 \%$ of the flats were without bathroom or lavatory convenience, a little bit more than $26 \%$ had washing facilities, more than $45 \%$ were normal convenience level and only two flats had full convenience level. After the reconstruction all 42 flats moved up to be on full convenience level, which practically means that in $95 \%$ of the flats there has been a positive increase in the convenience level. Comparing the size and the surface area of the flats we can see that though the number of flats became less, the average surface area of the flats has increased. While before, 30 flats were under the surface area of $50 \mathrm{~m} 2$, after the reconstruction only 12 had such size surface area. The number of flats with surface areas between $50-100 \mathrm{~m} 2$ has increased significantly (15 to 29 ) which also means a change in the positive direction. (Tab. 12 )

Table 9 Change in the number of flats

\begin{tabular}{|l|c|c|}
\hline \multirow{2}{*}{ Number of the house } & \multicolumn{2}{|c|}{ Number of flat (pc.) } \\
\cline { 2 - 3 } & $\mathbf{2 0 1 0}$ & $\mathbf{2 0 1 8}$ \\
\hline House 1 & 3 & 5 \\
\hline House 2 & 5 & 4 \\
\hline House 3 & 5 & 5 \\
\hline House 4 & 7 & 6 \\
\hline House 5 & 7 & 7 \\
\hline House 6 & 19 & 15 \\
\hline Total & 46 & 42 \\
\hline
\end{tabular}

Source: Own compilation based on the action area plan 
Table 10 Change in number of shops

\begin{tabular}{|l|c|c|}
\hline \multirow{2}{*}{ Number of the house } & \multicolumn{2}{|c|}{ Number of shops (pc.) } \\
\cline { 2 - 3 } & $\mathbf{2 0 1 0}$ & $\mathbf{2 0 1 8}$ \\
\hline House 1 & 1 & 1 \\
\hline House 2 & 1 & 1 \\
\hline House 3 & 0 & 0 \\
\hline House 4 & 0 & 0 \\
\hline House 5 & 2 & 3 \\
\hline House 6 & 0 & 0 \\
\hline Total & 4 & 5 \\
\hline
\end{tabular}

Source: Own compilation based on the action area plan

Table 11 Convenience level of flats before and after the first phase of the social urban rehabilitation

\begin{tabular}{|l|c|c|}
\hline \multirow{2}{*}{ Convenience level of the flats } & \multicolumn{2}{c|}{ Number of flats (pc) } \\
\cline { 2 - 3 } & $\mathbf{2 0 1 0}$ & $\mathbf{2 0 1 8}$ \\
\hline Without running water, sanitation and basic services & 11 & 0 \\
\hline Some basic services are available & 12 & 0 \\
\hline Individual heating system and all basic services are available & 21 & 0 \\
\hline Central heating system and all basic services are available & 2 & 42 \\
\hline Total & 46 & 42 \\
\hline
\end{tabular}

Source: Own compilation based on data provided by the Mayor's Office of Györ

Table 12 The surface area of flats before and after the first phase of the urban rehabilitation

\begin{tabular}{|l|c|c|}
\hline \multirow{2}{*}{ Surface area } & \multicolumn{2}{c|}{ Number of flats (pc) } \\
\cline { 2 - 3 } & $\mathbf{2 0 1 2}$ & $\mathbf{2 0 1 8}$ \\
\hline less than 50m2 & 30 & 12 \\
\hline $50-100 \mathrm{~m} 2$ & 15 & 29 \\
\hline more than 100m2 & 1 & 1 \\
\hline Total & 46 & 42 \\
\hline
\end{tabular}

Source: Own compilation based on data provided by the Mayor's Office of Györ

The modifications of the rental fees were also part of our examination. In case of municipal rental fees, it is important to state that several factors are taken into consideration when calculating them. By basic principle the rental fees are defined by product of the surface area of the flat, the numeric rate of the flat's use value and the unit fee (18/2004. (IV.16.) Municipal decree of Györ) When defining the use value of the flat, the level of convenience, the method of heating and construction, the level modernity as well as the flat's location within the residential area has to be taken into account. Before the start of the urban rehabilitation, in 2012 we got data from 19 flats concerning the rental fees because the rest of the flats were empty. The lowest rental fee was HUF 2880 for a $27 \mathrm{~m} 2$ flat without bathroom or lavatory facilities and the highest was HUF 14196 for a 120m2 flat of full convenience. As a result of the 
reconstruction the use value of the flats has risen significantly so naturally there is an increase in rental fees as well. After the reconstruction the rental fee of the smallest $32 \mathrm{~m} 2$ flat became HUF 12544 and for the biggest 124m2 flat HUF 43613 must be paid. So the rental fee of the highest quality flats has roughly tripled since the start.

We also compared the social status of the inhabitants of the 6 buildings examined, analysing the number of people receiving regular and temporary municipal support. Table 13 shows that while there is a small decrease in the number of people receiving permanent support, a significant drop has been experienced in the number of people receiving temporary support. Here we must note that in the involved flats the inhabitants have changed because not all inhabitants living there before the rehabilitation moved back after the rehabilitation. Many of the inhabitants living there chose to move into other municipal accommodation offered to them before the start of the reconstruction.

Table 13 Municipal support before and after the first phase of the urban rehabilitation

\begin{tabular}{|l|c|c|}
\hline Support provided by municipality & $\mathbf{2 0 1 2}$ & $\mathbf{2 0 1 8}$ \\
\hline Regular support (household) & 13 & 12 \\
\hline Temporary support (occasion) & 14 & 9 \\
\hline
\end{tabular}

Source: Own compilation based on data provided by the Mayor's Office of Győr

The summary of our comparative analysis is shown in Table 14. The changes in the hard infrastructure mainly show a positive picture, during the rehabilitation the built environment has significantly developed in case of these 6 houses. The number of shops for rent have risen which meant a sustainable income for the apartment buildings and also contributed to the variety of retail possibilities in the area. We can see that the level of convenience in these flats have changed positively, as all the flats reached the level of full convenience and in most cases the surface areas have increased as well thus providing higher quality living. Inevitably due to these changes the number of flats show a small decrease compared to the period before the rehabilitation.

Table 14 Result of the comparative analysis

\begin{tabular}{|l|l|c|}
\hline Examined factors & Indicators & Evaluation \\
\hline \multirow{4}{*}{ Change of hard infrastructure } & I1. Number of flats & - \\
\cline { 2 - 3 } & I2. Number of businesses & + \\
\cline { 2 - 3 } & I3. Level of conveniences of the flats & + \\
\cline { 2 - 3 } & I4. Surface area of the flats & + \\
\hline \multirow{3}{*}{ Change of soft factors } & I5. Rent prices & - \\
\cline { 2 - 3 } & I6. Applicants receiving regular support & + \\
\cline { 2 - 3 } & I7. Applicant receiving temporary support & + \\
\hline
\end{tabular}

Source: Own compilation 
During the period after the rehabilitation the development of the soft factors are contradictory. We have to evaluate the fact that the number of both the permanent and temporary support users dropped positively and come to the conclusion that the social status of the area has improved. This is a positive for the people living in the area even if this change was brought about by the municipality in a way that not all inhabitants were allowed to move back to their original dwellings (this is justified by the decrease of the number of flats). Looking at things from the social aspect however, we must draw our attention to the fact that the rental fees have tripled since the reconstruction. The reason for this was that the flats without basic facilities were turned into flats of full convenience with access to all services. This higher quality of service obviously meant higher prices. We also have to emphasise that these prices are still only a fraction of the real market price, so the inhabitants in these flats receive a significant discount which greatly helps them ensure their living near the city centre.

\section{DISCUSSION}

Every municipality in Hungary has had the opportunity to take part in social urban rehabilitation activities like Györ. Although we are at the moment in the phase of data collecting about practices of others, it is visible that other municipalities choosed for the place of rehabilitation predominantly housing estates with block of flats in contrast to rehabilitation activities in Györ that are realized in a historic part of the city. Because of this in our future researches it will be a hard work to make a comparison. But if we look previous findings regarding urban rehabilitation activities in Hungarian context we can also state the same. A comprehensive research from the early 2000s examined several sample area of urban rehabilitation in Hungary from the viewpont of the rehabilitation's effects (Egedy, 2005). The research focuced and examined parts of Budapest (Ferencváros, Józsefváros, Kőbánya, Újpest) and parts of other bigger Hungarian cities like Győr, Pécs, Szeged and Debrecen. With the exception of Köbánya where the urban rehabilitation activities focused on the renewal of historic city centre with eclectic and secessionist buildings, the others preferred the rehabilitation of housing estates (Egedy at al., 2002). The findings of this research stated that the rehabilitation makes a positive change in the residential situation of the population and in the housing mobility, furthermore we can witness a slow restructuring of social composition in the renovated parts of cities. It is important to highlight that these projects have focused on the physical renovation of the buildings and were not linked to social programs. 


\section{CONCLUSION}

In our study we strived to give a comprehensive picture of the social urban rehabilitation activity of the Györ Municipality, which really took off from the year 2012 even though there was need for the renovation and reconstruction of Újváros a run-down area of Győr way before this time. Choosing the social type of urban rehabilitation proved to be a very well-founded decision, as in the area not only the building stock needed reconstruction and renovation but the renewal of the local society, economy, environment all need to be focused upon by the project, primarily with the help of soft activities. Besides the examination of the empiric data proving the necessity of urban rehabilitation, great emphasis was put on the justification of urban rehabilitation. In the framework of the rehabilitation instead of the old flats that were in bad condition, the municipality is now able to offer 40 modern social dwellings for inhabitants in need providing flats of full convenience which definitely meant an increase in quality. Parallel to the development of the hard infrastructure, the soft activities offered by the social urban rehabilitation projects complement $\mathrm{A}$ and provide extra services to the inhabitants of the area. Our study was conducted using two aspects and seven indicators assigned to them. Over all positive changes were experienced during the urban rehabilitation project concerning both the hard infrastructure and the soft factors as well. There were definitely changes in quality in the area, the landscape became more aesthetic, the flats more comfortable and the status of the inhabitants strengthened. Undoubtedly in many cases this meant the moving away of the original inhabitants and the appearance of new inhabitants and the increase in rental fees. In the next part of our study after the end of the second phase of the urban rehabilitation project which is currently in progress we will strive to analyse it using similar aspects and indicators.

\section{REFERENCES}

Aase, G. \& Holt-Jensen, A. (2003). Evaluating housing and neighbourhood initiatives to improve the quality of life of deprived neighbourhoods. Bergu.

Alpopi, C. \& Manole, C. (2013). Integrated Urban Regeneration - Solution for Cities Revitalize. Procedia Economics and Finance, Volume 6, 178-185.

an Perspectives. Jessica Kingsley, London.

Anderson, M. (1967). The Federal bulldozer. A critical analysis of urban renewal. McGrawHill Publishing.

Atkinson, R. (2003). Addressing urban social exclusion through community involvement in urban regeneration. In Imrie, R . - Raco, M. (Ed.): Urban renaissance? New labour, community and urban policy. Bristol: The Policy Press. 101-120.

Budai, I. \& Puli, E. (2014). Az együttműködés vizsgálata a szociális szolgáltatásokban [Examining co-operation in social services]. Az altéma-kutatás eredményeinek összegzése. [Analysis of the sub-theme research results] In Csizmadia Z. \& Tóth P. 
(Eds.): A helyi társadalom és intézményrendszer Györben. [Local society and institution system in Györ] Győr: Universitas-Györ Nonprofit Kft., 272-290.

Budai, I. (2014). Az együttmüködés mint a szociális szolgáltatásokban folyó tevékenység egyik építököve. [Co-operation as the building block of activities in social services] In Csizmadia, Z. \& Tóth, P. (Eds.): A helyi társadalom és intézményrendszer Györben. [Local society and institution system in Györ] Györ: Universitas-Györ Nonprofit Kft., 230-244.

Bugovics, Z. (2014). A győri identitás háttértényezőinek vizsgálata. (Examining the background factors of the Györ identity) In Csizmadia Z. \& Tóth P. (Eds.): A helyi társadalom és intézményrendszer Györben. [Local society and institution system in Györ] Győr: Universitas-Győr Nonprofit Kft.,100-115.

Cruz, C. O. \& de Brito, J. (2015). Role of Public Administration in Fostering Urban Housing Rehabilitation. Journal of Urban Planning and Development, Volume 141, Issue 4.

Csizmadia, Z. \& Tóth, P. (2014). Egy magyar nagyváros társadalmának szerkezete a XXI. század első felében. [Social structure of a Hungarian metropolis in the first half of the 21st century] Bevezető tanulmány társadalomszerkezeti kitekintéssel. [An introductory study with a glimpse on social structure] In Csizmadia Z. \& Tóth P. (Eds.): A helyi társadalom és intézményrendszer Györben. [Local society and institution system in Györ] Győr: Universitas-Győr Nonprofit Kft., 7-28.

Csizmadia, Z. (2014). A szociális intézményrendszer szereplőinek hálózati struktúrája. [The network structure of the participants of the social insitution system] In Csizmadia Z. \& Tóth P. (Eds.): A helyi társadalom és intézményrendszer Györben. [Local society and institution system in Győr] Győr: Universitas-Győr Nonprofit Kft., 245-271.

Czakó, K. \& Döry, T. (2016). A területi töke koncepciója és a városi vállalkozáskutatás. (The concept of territorial capital and urban business research) Tér és társadalom. 30. évf. 1. sz. 18-36. [Space and society. Volume 30 issue 1 pp 18-36.]

Czakó, K. \& Hajdu-Smahó, M. (2014). Vállalati nyitottság vizsgálata a Győri Jármüipari Körzet területi tökéjében. [Research of business openness in the territorial capital of the Győr Vehicle Engineering Region) In Lados M. (Ed.): A gazdaságszerkezet és vonzáskörzet alakulása. [Development of the economic structure and agglomeration] Győr: Universitas-Győr Nonprofit Kft., 216-229.

Dusek, T. (2014). A közszolgáltatások területi és szervezeti hatékonysága és győri integrációja [Territorial and organisational efficiency and integration of public services in Győr] In Dusek T. (Ed.): A városi rendszer müködése: Közösségi szféra, oktatás és Györ jövöképe. [Operation of the city's system: social sphere, education and the future vision of Györ] Győr: Universitas-Győr Nonprofit Kft., 45-54.

Egedy, T. (2005). A városrehablitáció hatásai a lakásmobilitásra és a társadalmi mozgásfolyamatokra [Urban rehabilitation's effect on housing mobility and social movement processes] In: Egedy T. (Ed.): Városrehabilitáció és társadalom, Magyar Tudományos Akadémia, Földrajztudományi Kutatóintézet, Budapest, 9-21. [Urban rehabilitation and society, Hungarian Academy of Sciences, Geographical Institute, Budapest, 103-158]

Egedy, T. \& Kovács, Z. (2005). A városrehabilitáció néhány elméleti kérdése [Theoretical questions of urban rehabilitation] In: Egedy T. (Ed.): Városrehabilitáció és társadalom, Magyar Tudományos Akadémia, Földrajztudományi Kutatóintézet, Budapest, 9-21. [Urban rehabilitation and society, Hungarian Academy of Sciences, Geographical Institute, Budapest, 9-21]

Egedy, T., Kovács, Z., Székely, G. \& Szemző, H. (2002). Városrehabilitációs programok eredményei és tapasztalatai Budapesten. Falu Város Régió, 2002, Issue 8,3-10. [Results and experiences of urban rehabilitation programs in Budapest] 
Fekete, D. (2014). Györ aktuális jövőképe a város stratégiai dokumentumainak tükrében. [The future vision of Györ through the strategic documents] In: Dusek T. (Ed.): A városi rendszer müködése: Közösségi szféra, oktatás és Györ jövöképe. [Operation of the city's system: social sphere, education and the future vision of Györ] Györ: Universitas-Györ Nonprofit Kft., 180-187.

Fekete, D. (2018a). 25 éve Györben az AUDI [AUDI, 25 years in Győr]: A kutatás eddigi eredményeinek összegzése. [Summary of the research result] TÉR - GAZDASÁG EMBER, VI. évfolyam, 1. szám, 9-24. [SPACE-ECONOMY-MANKIND, Volume VI. Issue 1, 9-24]

Fekete, D. (2018b). Latest results of the Györ Cooperation Model. Civic Review. Vol. 14, Special Issue, 195-209.

Fekete, D. (2018c): Economic Development and Economic Governance Through the Example of the City of Györ. Deturope. Vol. 10, Issue 1. 97-115.

Holt-Jensen, A \& Morrison, N. (2000). NEHOM. Neighbourhood Housing Models - Special issue on Social exclusion and community initiatives. GeoJournal, Volume 51, 4.,277363.

Holt-Jensen, A., Henu, A., Kahrik, A.\& Liias, R. (2004). New Ideas for Neighbourhoods in Europe. Handbook. Tut Press, Bergen-Tallinn.

Honvári, P. (2014). Győr agglomerációs kutatása és eredményei a 60-as évektől napjainkig [Research and Results of the Györ agglomeration from the 1960's to the present] In Lados M. (Ed): A gazdaságszerkezet és vonzáskörzet alakulása. [Development of the economic structure and agglomeration] Győr: Universitas-Győr Nonprofit Kft., 7-22.

Kovács, G. (2014). A lokális források szerepe a helyi önkormányzatok finanszírozásában: [The role of regional resources in financing local municipalities] Győr MJV forrásbevonási stratégiájának elemzése. [The strategic analysis of fundraising in Győr.] In Dusek T. (Ed.): A városi rendszer müködése: Közösségi szféra, oktatás és Györ jövőképe. [Operation of the city's system: social sphere, education and the future vision of Győr] Győr: Universitas-Győr Nonprofit Kft., 28-44.

Laczkovits-Takács, T. (2018). Győr humánszolgáltatási modelljének egészségügyi pillére 1990-töl napjainkig. [The health pillar of Györ's human services model from the 1990's to the present] Polgári Szemle, 14. évfolyam, 1-3. szám 90-106. [Civic Review, Volume 14 , issue 1-3, 90-106.]

Lichfield, D. (1992). Urban regeneration for the 1990s. London Planning Advisory Committee, London.

McGregor, A. \& McConnachie, M. (1995). Social Exclusion, Urban Regeneration and Economic Reintegration. Urban Studies, 32(10), 1587-1600.

Mendes, L. (2013). Public policies on urban rehabilitation and their effects on gentrification in Lisbon. AGIR - +. Volume 1, Numero 5, 200-218.

Nárai, M. (2014a). Humán szükségletek alakulás Győrben I. - Alapszükségletek. [Develponment of Human Needs in Györ I. - Basic Needs] In Csizmadia Z. \& Tóth P. (Ed.): A helyi társadalom és intézményrendszer Györben. [Local society and institution system in Győr] Győr: Universitas-Győr Nonprofit Kft., 154-181.

Nárai, M. (2014b). Humán szükségletek alakulás Győrben II. - Magasabb rendü aktivitási szükségletek. [Development of human needs II. - Higer level activity needs] In Csizmadia, Z. \& Tóth, P. (Eds.): A helyi társadalom és intézményrendszer Györben. [Local society and institution system in Györ] Győr: Universitas-Györ Nonprofit Kft., 182-200.

Páthy, Á. (2014). A társadalmi szerkezet belső területi sajátosságai [The local territorial character of the society's structure] In Csizmadia Zoltán \& Tóth Péter (Eds.): $A$ helyi 
társadalom és intézményrendszer Györben. [Local society and institution system in Györ] Győr: Universitas-Győr Nonprofit Kft., 48-74.

Rechnitzer J., Kecskés P. \& Reisinger A. (2016). A Győri Modell - Az Egyetem, az ipar és a város együttmüködési dimenziói. [The Györ Model - The dimensions of co-operation between the University, the industry and the city] In Lengyel I. \& Nagy B. (Eds.): Térségek versenyképessége, intelligens szakosodása és újraiparosodása. [Competitiveness, intelligent specialisation and re-industrialisation of regions]. Szeged: JATE Press Kiadó, 225-239.

Rechnitzer, J. (2014). A győri gazdaság pályapontjai a rendszerváltástól napjainkig. [The trackpoint of the Györ economy from the change of regime to the present] In Lados M. (Ed.): A gazdasági szerkezet és vonzáskörzet alakulása. [Development of the economic structure and agglomeration] Győr: Universitas-Győr Nonprofit Kft., 104-129.

Rechnitzer, J. (2016). A területi töke a városfejlödésben. [Territorial capital in urban development] Budapest-Pécs: Dialóg Campus Kiadó.

Reisinger, A., Kecskés, P. \& Czakó, K. (2017). Services of Economic Development Organisations in Győr. Deturope, 9 (3), 85-100.

Reisinger, A. (2014a). Társadalmi részvétel - ahogy a győriek látják [Social participation - how the people of Györ see it] In Csizmadia Z. \& Tóth P. (Ed.): A helyi társadalom és intézményrendszer Györben. [Local society and institution system in Györ] Győr: Universitas-Győr Nonprofit Kft., 116-128.

Reisinger, A. (2014b). Vállalatok kapcsolati hálója Győrben és térségében [Contact network of companies in and around Györ] In Lados M. (Ed.): A gazdaságszerkezet és vonzáskörzet alakulása. [Development of the economic structure and agglomeration] Györ: Universitas-Györ Nonprofit Kft., 230-243.

Róbert, P. (2014). Társadalmi rétegződés és mobilitás [Social stratification and mobility] In Csizmadia, Z. \& Tóth, P. (Eds.): A helyi társadalom és intézményrendszer Györben. [Local society and institution system in Györ] Györ: Universitas-Györ Nonprofit Kft., 28-47.

Somlyódyné Pfeil, E. (2014). A városkérdés a módosult állami szerepfelfogás keretei között. [Special regard to Györ within the framework of the modified role of the state] In Hardi T. - Somlyódyné Pfeil, E. (Eds..): Városfejlödési trendek és állami szerepek. [Urban development trends and the role of the state] Györ: Universitas-Györ Nonprofit Kft., 103111.

Steinberg, F. (1996). Conservation and rehabilitation of urban heritage in developing countries. Habitat International, Volume 20, Issue 3, 463-475.

Stöhr, W. (1989). Regional policy at he Crosswords: an overview. In Albrechts, L., Moulaert, F., Roberts, R. \& Swyngedlouw, E. (eds.): Regional Policy at the Crossroads: Europe

Szörényiné Kukorelli, I. (2014). Város és vidéke - térkapcsolatok elemzése Győr térségében [The city and its regions - Analysis of Spacial Interaction in Györ region] In Lados M. (Ed): A gazdaságszerkezet és vonzáskörzet alakulása. [Development of the economic structure and agglomeration] Györ: Universitas-Györ Nonprofit Kft., 22-49.

Tasan-Kok, T. (2003). European Union and Urban regeneration activities: URBAN I. and II. and Community Initiative Programmes.

Tóth, P. \& Ditrói, Z. (2014). A helyi társadalom dimenziói [Dimensions of the local society] In Csizmadia Z. \& Tóth P. (Eds.): A helyi társadalom és intézményrendszer Györben. [Local society and institution system in Győr] Győr: Universitas-Győr Nonprofit Kft., 75-99.

Wrigley, N., Guy, C. \& Lowe, M. (2002). Urban Regeneration, Social Inclusion and Large Store Development: The Seacroft Development in Context. Urban Studies, 39(11), 21012114. 
Yung, E.H.K., Chan, E.H.W. \& Xu, Y. (2014). Sustainable Development and the Rehabilitation of a Historic Urban District - Social Sustainability in the Case of Tianzifang in Shanghai. Sustainable Development, 22, 95-112.

1/14/10/2016. PM. határozat - Győr Megyei Jogú Város Polgármesterének határozata a „Megyei jogú városok leromlott városi területeinek rehabilitációja” címü, TOP-6.7.1-15 azonosító számú felhívásra pályázat benyújtásáról [Mayor's Decision 1/14/10/2016. on the tender called „Rehabilitation of areas in poor condition in municipal cities submitted based on the call no. TOP-6.7.1-15"]

133/2012. (V.25.) GYÖR MJV Kgy. sz. határozat - Javaslat a 38/2011. (IV. 29.) Kgy. sz. határozat módosítására és az NYDOP-3.1.1/B-09-1f-2011-0001 kódszámú, "Szociális városrehabilitáció Győr-Újváros területén" című projektjavaslat második körös pályázati anyagát képező Akcióterületi Terv elfogadására [133/2012. (V.25.) Decision of the Győr General Assembly - Proposal to modify the 38/2011. (IV. 29.) decision of the Györ General Assembly and to accept the Action Area Plan of the second round project proposal called „Social Urban Rehabilitation in Győr-Újváros under the code NYDOP3.1.1/B-09-1f-2011-0001]

142/2016. (IX.23.) GYÖR MJV Kgy. sz. határozat - Javaslat Győr Megyei Jogú Város Integrált Településfejlesztési Stratégiájának módosítása [142/2016. (IX.23.) Decision of the Győr General Assembly - Modification of Integrated Settlement Development Strategy of Györ]

162/2014. (IX.12.) GYÖR MJV Kgy. sz. határozat - Győr Megyei Jogú Város Integrált Településfejlesztési Stratégiája [162/2014. (IX.12.) Decision of the Györ General Assembly on the Integrated Settlement Development Strategy of Györ]

18/2004. (IV.16.) GYÖRMJVÖ rendelet - az önkormányzati lakások lakbérének mértékéröl, a külön szolgáltatási díjakról, ezek megfizetésének módjáról [Győr Municipal Decree on the rate of rental fees of municipal dwellings, separate service fees and their ways of payment]

22/04/05/2016. PM. határozat - Győr Megyei Jogú Város Polgármesterének határozata „A társadalmi együttmüködést erősítését szolgáló helyi szintü komplex programok" címü, TOP-6.9.1-15 azonosító számú felhívásra pályázat benyújtásáról [Mayor's Decision $22 / 04 / 05 / 2016$. on the the tender called „Complex local level programmes enhancing social co-operation" submitted based on the call no. TOP-6.9.1-15]

312/2012. (XI.8.) Korm. rendelet a településfejlesztési koncepcióról, az integrált településfejlesztési stratégiáról és a településrendezési eszközökről, valamint egyes településrendezési sajátos jogintézményekről [312/2012. (XI.8.) Governmental decree on the urban development concept, the integrated settlement development strategy, urban planning tools and special legal institutions]

38/2011. (II.25.) GYÖR MJV Kgy. sz. határozat - Javalat a NYDOP-2009-3.1.1/B. kódszámú pályázati felhívásra elkészített "Szociális városrehabilitáció Győr-Újváros területén" címü projektjavaslat első körös pályázati anyagát képező Előzetes Akcióterületi Terv és a projektköltségvetés elfogadására, valamint a pályázat első körös fordulójára történő benyújtásra [38/2011. (II.25.) Decision of the Györ General Assembly - Proposal to accept the Premliminary Action Area Plan and the project budget and to submit the tender prepared for the call code number NYDOP-2009-3.1.1/B. unded the name „Social Urban Rehabilitation of Győr-Újváros".]

41/2008. (II.28.) GYÖR MJV Kgy. sz. határozat - Győr Megyei Jogú Város Integrált Városfejlesztési Stratégiája [41/2008. (II.28.) Decision of the Győr General Assembly Integrated Urban Development Strategy of Györ] 
5/2015. (II.27.) GYÖRMJVÖ rendelet - a szociális igazgatás és szociális ellátások helyi szabályozásáról [5/2015. (II.27.) Municipal decree on the local regulation of social management and social services]

Akcióterületi terv (2012). Megyei Jogú Városok városrehabilitációs témájú kiemelt projekt javaslatai NYDOP-2009-3.1.1/B - Szociális városrehabilitáció Győr-Újváros területén [Action plan (2012) Emphasized project proposals in the topic of urban rehabilitation of municipal cities]

Közösségi beavatkozási terv (2016). „Györ-Újváros szociális városrehabilitációhoz kapcsolódó társadalmi együttmüködést erősítő komplex program” TOP-6.9.1-15-GY1-2016-00001 [Community intervention plan (2016). TOP-6.9.1-15-GY1-2016-00001 - Complex program for strengthening social cooperation related to social urban rehabilitation of Győr-Újváros]

Megvalósíthatósági tanulmány (2016). TOP-6.7.1-15-GY1-2016-00001 - „Szociális városrehabilitáció Győr-Újváros területén, II. ütem [Feasibility study (2016) TOP-6.7.115-GY1-2016-00001 - in the field of Social Urban Rehabilitation of Györ-Újváros, 2nd phase.] 